\title{
Critical Appraisal of Third Party Funding in India
}

\author{
Ms. Seemasmiti Pattjoshi \\ Ph.D. Scholar, KIIT School of Law, Bhubaneswar, mail: pattjoshi.seema@gmail.com \\ Dr. Puranjoy Ghosh \\ Assistant Professor, KIIT School of Law, Bhubaneswar, mail: puranjoyghosg@kls.ac.in
}

\begin{abstract}
Third-party funding in International Commercial Arbitration is one of the most contemporaneous and controversial issue in the normative framework in India. The last several years have witnessed increasing involvement of Third Party Funders in International Commercial Arbitration proceedings. Third-party funding has been considered as one of the means of access to justice for those who have a credible claim but no financial means to pursue it. Dispute resolution in India tends to be a costheavy proposition for the parties involved. The present discussion highlights critical appraisal regarding TPF (Third Party Funding) from the delivery of procedural and substantive justice as well as suggesting legal and jurisprudential grounds in third party funding governance all across the world.
\end{abstract}

Keywords:

Third party funding, justice, access to justice, international commercial arbitration

Article Received: 18 October 2020, Revised: 3 November 2020, Accepted: 24 December 2020

\section{INTRODUCTION}

Third Party Funding in International Commercial Arbitration as well as Investment Arbitration has become widespread practice over the years and Singapore being one of the developed countries and member of ASEAN has on March, 2017 already given effect to Third Party Funding practice in International arbitration and related court proceedings by amending its "Civil Law being Civil Law (Amendment) Act (Bill No. 38/2016)". "Singapore International Arbitration Centre (SIAC) has provided the arbitral tribunal the power to order disclosure of the existence of a funding arrangement entered into by one of the parties to the proceedings, the identity of the third-party funder involved and further details on the third-party funder's involvement and interest in the outcome of the case". Hong Kong has also followed by adopting the "Arbitration and Mediation Legislation (Third Party Funding)(Amendment) Bill 2016 on 14 June 2017" which is much similar to that of Singapore. On 31 August 2017, the "China International Economic and Trade Arbitration Commission Hong Kong Arbitration Center (CIETAC) released its Guidelines on Third Party Funding in Arbitration". It is also connected with 'investment process in litigation or arbitration mechanism', in which the funder/investor promotes finance in a case exchange for a portion of awarded amount. "The Comprehensive Economic and Trade Agreement (CETA) between Canada and the European Union dated 14 September 2016 contains explicit provisions on third-party funding". "The Transatlantic Trade and Investment Partnership (TTIP), which is currently available in proposed form only, also includes rules on third-party funding". Finally, the "International Centre for Settlement of Investment Disputes (ICSID) is currently working on a way to address third-party funding in arbitrations conducted under the ICSID Rules of Procedure for Arbitration Proceedings (Arbitration Rules), 2006 ".

It is a common observation that topic of the 'Third Party Funding' and that too in 'International Commercial Arbitration' has not being considered in India to be an effective mechanism to promote India as one of the efficient International Commercial Arbitration hub reason being the 
conformist approach against it as violative of public policy. Since this context has gained much currency in the International Commercial Arbitration regime, we felt the urge to work upon the same and endeavour to produce some original research work; which not only, will enrich this area of International Arbitration but will also become immensely useful to those claimants who face the crisis of injustice to their opponent just because lack of financial ability to pursue the suit and which makes huge loss to the justice system because our Constitution says "Justice can be delayed but cannot be denied".

Jurisdictions around the world have been bringing about necessary changes to their legal regimes in order to legalize and provide for third party funding of legal proceedings, including Hong Kong, Singapore and other ASIEN Countries. As a result, a great number of the developed and ASEAN countries have begun to adopt the TPF mechanism to access the justice quickly, efficiently and economically. In this context, third-party funding in India would enable not only access to justice, but effective access to justice. The financing provided to parties would allow them to pursue meritorious and legitimate claims, reasonably unfettered by financial constraints. The research done in this field will thus be useful to enrich the practices of TPF in Indian Legal System to maintain global legal order in International Commercial Arbitration too.

- To ascertain the grounds of increasing practices of TPF mechanism in International Commercial Arbitration in various developed countries;

- To examine the suitability of the mechanism of TPF practice in Indian Legal system to maintain global legal order of transnational commercial dispute resolution in International Commercial Arbitration;

\section{SIGNIFICANCE OF THIRD PARTY} FUNDING IN INTERNATIONAL COMMERCIAL ARBITRATION
International Commercial Dispute Resolution mechanism has experienced such a tremendous growth in the last few decades that it has now become a victim of its own success. The distinct characteristics of 'speedy disposal', 'parties' autonomy in choice of law', 'seat of arbitration', and so on, inspired the efficacy of such alternative mode of dispute resolution mechanism. Third Party Funding, is one such practice that has gained much vibrancy especially in International Commercial Dispute Resolution mechanism. The emerging numbers of Financers (Funders) in the Litigation Markets in some developed countries of the globe, facilitating the prospective claimants in accessing to the Justice in today's fast-economy. Third Party Funding (hereinafter referred to as TPF) which was categorically criticized earlier and abandoned by law-makers in various legal frameworks treating it to be contrary to the Public Policy. However, the tortuous principles of Maintenance and Champerty regained its access particularly from late 2012 and early 2013 in International Commercial Dispute Resolution and some developed countries, for example, Australia, the United Kingdom and the United States, Canada, Singapore have already endorsed TPF practice in International Commercial Arbitration Proceedings in their legal frameworks. The International Council for Commercial Arbitration (ICCA), alongside the Queen Mary University of London established a Joint Task Force in 2014 to study the present theme and to propose the best practices. For that, experts from all corners of the world were assembled. After long three years' discussion an initial Draft was made available for public and professional scrutiny in September 2017.

In today's fast global economy TPF serves two primary objectives - a) an easy mode of financing; and b) saving the valuable corporate time. The chequered history of intrusion of financers in the administration of civil justice during Mercantile Capitalism, as stated above, guided the lawsystems of some countries to deny the intrusion of such financers from its legal frameworks to ensure 
the core values of justice system and made it as elementary aspect in determining the Public Policy. Over the years the opinions of the policymakers was relating to higher probability of defeat of fairness and fair process of law by such Financers, if allowed in the litigation markets, hence, treated such TPF as deterrent to the administration of justice system and envisaged it to be against the public policy. Of late, the trends of trade-liberalization encouraged the convergence of the legal cultures across the nations and to attune and set a global economic order. And the recent practice of Third Party Funding (the socalled Financers)in the litigation markets has been found to have been cooperating in facilitating to the access to justice to the prospective claimant to arbitration dispute, and as such funding prohibitions make little sense today.

With Third Party Funding mechanism gaining increasing global significance in providing parties' access to justice, the time has come for India to formally open its doors to dispute financing in International Commercial Arbitration. Third-party funding in International Commercial Arbitration is one of the most current and controversial issues in international arbitration. The last several years have witnessed a tremendous increase in the participation of Third Party Funders in International Commercial Arbitration. Third-party funding has been promoted as a way of accessing justice for those who have a credible claim but no financial means to pursue it.

As mentioned earlier, perhaps the widely acknowledged benefit of third-party funding is realizing the public policy objective of increasing access to justice. In India, access to justice is recognized as a fundamental right under Articles 14 and 21 of the Indian Constitution and is guaranteed to every citizen in the country. As an alternative to long drawn-out court litigation where cases languish for years without resolution, commercial arbitration has provided much needed relief to disputants in India.
In this context, third-party funding in India would enable not only access to justice, but effective access to justice. The financing provided to parties would allow them to pursue meritorious and legitimate claims, reasonably unfettered by financial constraints.

Another direct impact of third-party funding would be reduced workloads for the already overburdened litigation system in India. Access to speedier methods of dispute resolution would help reduce the backlog of cases in the Indian judicial system, by diverting litigants to more attractive fora. The possibility of third-party funding encouraging frivolous proceedings before arbitral tribunals or courts is a fear stemming from the traditional public policy considerations prohibiting champerty and maintenance. However, the exhaustive due diligence conducted by funders prior to entering into funding agreements would go a long way towards ensuring that only meritorious claims receive funding.

\section{LEGAL PROVISIONS ON THIRD PARTY LITIGATION FUNDING IN INDIAN LAW}

\subsection{Civil Procedure Code, 1908}

Indian law does not have specific provisions on TPLF, but the wording of Sec.35 of Code of Civil Procedure (CPC) can be read to infer that, in certain circumstances the cost may be awarded to a third party by the Court. Costs are in the discretion of the Court that is adjudicating the matter. Judicial discretion cannot be exercised by the Courts without keeping in mind the general legal principles. Moreover, some States have amended Order XXV to cover cases in which the plaintiff is financed by a third party. For example, Order XXV of CPC was amended for the State of Maharashtra $^{1}$, and it states that in cases where a

\footnotetext{
1 Order XXV of CPC was amended for Maharashtra by Bombay High Court Notification P. 0102/77 dated 5-91983. This same amendment has been adopted by Gujarat and Madhya Pradesh. Allahabad has added only R. 2 of Or. 25 , which states that costs may be secured from the thirdparty funding of litigation.
} 
third party is financing a plaintiff for some returns, "the Court may order such person to be made a plaintiff to the suit, if he consents, and may either of its own motion or on the application of any defendant order such person, within a time to be fixed by it, to give security for the payment of all costs incurred and likely to be incurred by any defendant". ${ }^{2}$

In the case of Maniankutty $v$. Venkiteswaran, ${ }^{3}$ the Court observed that "it cannot be said that [the] Court has no power to award costs against persons, who are not parties to the suit in exceptional cases".

\subsection{The Indian Contract Act, 1872}

Section 23 of the Indian Contract Act states that the consideration or object of an agreement is unlawful, if the Court regards it as immoral, or opposed to public policy, and such agreements are void. The definition of and scope of "public policy" can be determined through judicial precedents. In Fender v. St. John Milday, ${ }^{4}$ Lord Atkin observed that "the doctrine does not extend only to harmful effects, it has to be applied to harmful tendencies. Here the ground is less safe and treacherous". Furthermore, in ONGC Saw Pipes case, ${ }^{5}$ the Supreme Court of India observed that "The concept of what is for the public good or in the public interest or what would be injurious or harmful to the public good or the public interest has varied from time to time". The term public policy has been held to include "tending to the perversion of or interference with the administration of justice". This head covers maintenance, champerty, and agreements to stifle prosecution. Ergo, agreements of maintenance and champerty that tend to the perversion or interference with the administration of justice have been held void. A similar observation has

\footnotetext{
${ }^{2}$ Maniankutty v. Venkiteswaran, (1978) KLT 841 at 842.

3 ibid

${ }^{4}$ Fender v. St. John Milday, 1983 AC 1 (HC).

${ }^{5}$ ONGC Ltd. v. Saw Pipes Ltd., 2003 (2) RAJ 1 (SC).
}

been made by Supreme Courts in cases like $M r$. G. and A.K. Balaji. ${ }^{6}$

In fact, the Privy Council, in 1893, in the case of Kunwar Ram Lal v. Nil Kanth 1893 SCC OnLine PC 7] went so far as to hold that "Agreements to share the subject of litigation, if recovered in consideration of supplying funds to carry it on, are not in themselves opposed to public policy". Previously, in AhmedbhoyHubibhoy v. VullebhoyCassumbhoy [(1882) 6 Bom. 703], an agreement to purchase a pendente lite property leaving the vendor no interest in the property, was held not to be champertous.

Section 70 of the Indian Contract Act states that in situations where in a non-gratuitous act by a person (or a third party) benefits another person, the person receiving the benefits is bound to make good for, or compensate the person that has engaged in the non-gratuitous act. This provision may be relevant for cases of pure funding, wherein funders are motivated to financially support the claim of a party non-gratuitously. This section is not applicable in cases of commercial funding, where the funding is mainly done for monetary returns or profit. It has also been noted by the Supreme Court that Section 70 of the Indian Contract Act does not apply to cases where there is a subsisting contract. ${ }^{7}$ Therefore, if the pure funding is done vide a contract, Section 70 of the Indian Contract Act will not apply, and the act by the third party will become gratuitous.

\subsection{Bar council of India Rules}

The Bar Council of India Rules ${ }^{8}$ do not explicitly prohibit litigation funding by advocates. However, it has been noted in the A.K. Balaji case that " $a$ conjoint reading of Rule 18 (fomenting litigation), Rule 20 (contingency fees), Rule 21 (share or interest in an actionable claim) and Rule

\footnotetext{
${ }^{6}$ Bar Council of India v. A.K. Balaji and others, 2018 (5) SCC 379. And In Re: Mr. 'G', A Senior Advocate of the Supreme Court v. The Hon'ble Chief Justice and Judges of the High Court of Judicature at Bombay, 19551 SCR 490.

${ }^{7}$ Mulamchand v. State of Madhya Pradesh, 1968 SCR (3) 214.

8 The Bar Council of India Rules, 1975.
} 
22 (participating in bids in execution, etc.)" indicates that advocates in India cannot fund the litigation on behalf of their clients. Third party funding by lawyers, albeit not unknown, has been a sensitive issue worldwide.

In India, there is a specific prohibition on lawyers funding their clients' legal proceedings, and on charging them fees on a contingency basis. The Bar Council of India Rules prohibit advocates from charging their clients a fee which is contingent on the result of the litigation, or to be paid a percentage or share of the claims awarded by the Court. Part VI, Chapter II, Section II, Rule 20 of the Bar Council of India Rules (Standard of Professional Conduct and Etiquette) states - "An advocate shall not stipulate for a fee contingent on the results of litigation or agree to share the proceeds thereof".

The Supreme Court in Bar Council of India v. AK Balaji (2015), has clarified the legal permissibility of TPF in litigation and observed that "There appears to be no restriction on third parties (nonlawyers) funding the litigation and getting repaid after the outcome of the litigation." "The (Indian) Code of Civil Procedure, 1908, (Order XXV Rule 3) as amended by a few Indian states including Maharashtra, Karnataka, Gujarat and MP, expressly acknowledges the role of the third-party financier of litigation costs of a plaintiff, and sets out the situations when such financier may be made a party to the proceedings. However, as on date, there is no legislative instrument that regulates such funding".

\section{CONCLUSION}

The polemical issue of TPF legitimacy in international arbitration is primarily related to the common law doctrines of maintenance and champerty. These doctrines may very likely serve to constrain the existence, validity, and viability of any TPF agreement in jurisdictions where their application persists.

In reality as the Arbitration and Conciliation Act of 2015 is silent on this aspect, it has been taken to be as non-existent in India and till date, there is no such instance where third party funding has been used in arbitration proceedings. However, if third party funding is taken as a champerty contract which are contracts where the returns are contingent on the result, it doesn't render it per se illegal except in cases where an advocate may be an party and also in cases, where the consideration of the agreement goes against any such law like gambling debt recovery then, it is rendered illegal by the Contract Act of 1872 .

Dispute resolution in India tends to be a costheavy proposition for the parties involved. A party's legal costs and expenses, expert fees, arbitrator fees, registration fees to the administering institution, and other fees tend to make international commercial arbitration an expensive affair. Thus, the advantages of thirdparty funding in international commercial arbitration cannot be refuted.

If in case, the third party funding mechanism are still restricted to practice in the dispute resolution mechanism in India then it seems India will lack behind as an arbitration hub in International Commercial Arbitration.

\section{REFERENCES}

[1] William Park (Boston University), Stavros Brekoulakis (Queen Mary University of London),"A Preview of the Forthcoming ICCA-Queen Mary Report on Third-Party Funding”, April 5, 2018.

[2] Marc Krestin, Rebecca Mulder, "ThirdParty Funding In International Arbitration: To Regulate Or Not To Regulate?',Kluwer Arbitration Blog, December 12, 2017.

[3] Oliver Gayner; Susanna Khouri, Singapore and Hong Kong: International Arbitration Meets Third Party Funding, 40 HEINONLINE 1033 (2017).

[4] Maxi Scherer; Aren Goldsmith, Third Party Funding in International Arbitration in Europe: Part 1 - Funders' Perspectives, 2012 Int'l Bus. L.J. 207 (2012)

[5] Maria Choi, Third-Party Funders in International Arbitration: A Case for 
Protecting Communication Made in Order to Finance Arbitration, 29 Geo. J. Legal Ethics 883 (2016).

[6] George R. Barker, Third-Party Litigation Funding in Australia and Europe, 8 J.L. Econ. \&Pol'y 451 (2012).

[7] C. BOGART, "Third party funding in international arbitration", Burford Capital 22 January 2013. 